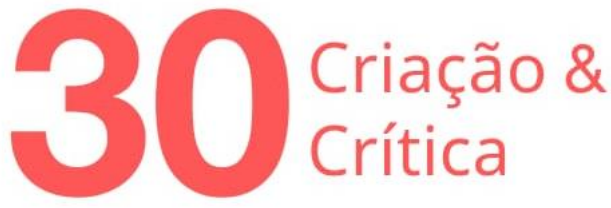

\section{FILOLOGIA ATIVA: BARTHES E NIETZSCHE}

Shane Weller ${ }^{1}$

\section{Apresentação da tradução}

Julia Bunemer Nojiri²

A presente tradução tem por objetivo contribuir para a divulgação de pesquisas acerca da influência germânica no pensamento de Roland Barthes: ainda que se tenha aí um amplo campo de estudos, esse está longe de se esgotar.

Isso, pois, como veremos adiante no artigo, tal pesquisa é uma empreitada em muitos sentidos, sendo um deles o mais óbvio - o fato de que Barthes não lia em alemão, coisa que ao passo que atiça a curiosidade do pesquisador é também um problema que pode enredá-lo, já que tal fato dificulta que se rastreie por onde passaram tais leituras, sempre traduzidas e mediadas.

Contudo, em certo sentido, pode-se dizer que se tem nesse problema a sua solução: compreender a influência dos escritos germânicos no bojo da cultura e da língua amadas por Barthes, fazendo-se necessárias as leituras de Derrida e Deleuze, especialmente no tocante aos estudos nietzschianos e talvez o mais importante para sua solução, isso é, sermos barthesianos antes de tentarmos enquadrar Barthes, como o faz Shane Weller a seguir, repensando a relação de Nietzsche com Barthes no cerne do projeto barthesiano de libertação textual, obviamente barrando qualquer possibilidade de rastreamento teórico assertivo.

Para tanto, aqui optamos por manter o artigo o mais fidedigno possível ao original, de modo a ajudar o leitor, uma vez que isso se trata de uma tradução brasileira de um artigo inglês sobre a influência germânica no pensamento de um francês. Assim, em português fluente, aqui o leitor terá acesso à leitura de Shane Weller traduzida em léxico mais sóbrio e técnico, reproduzindo-se o original. Sobre as citações e referências feitas pelo autor, aqui se encontra seu equivalente em versão brasileira seguindo este padrão: tudo foi vertido do inglês, salvo as referências bibliográficas sem tradução brasileira. O uso do francês neste artigo foi mantido embora traduzido em notas de rodapé ou no próprio corpo do texto (também de modo a não nos

\footnotetext{
${ }^{1}$ Segundo vice-chanceler de pesquisa e inovação da Universidade de Kent e professor de Literatura Comparada na mesma instituição. E-mail para contato: s.j.weller@kent.ac.uk.

${ }^{2}$ Graduanda em Filosofia com pesquisa em andamento no departamento de Letras Modernas na Universidade de São Paulo. Bolsista do CNPq. E-mail para contato: julia.nojiri@usp.br.
} 


\section{Criação \&}

afastarmos do autor nem aumentarmos as notas de rodapé), de maneira que todas as citações e referências que não se encontrarão aqui em português é devido ao fato de não estarem traduzidas, salvo $O$ Prazer do texto, do qual optamos por fazer a nossa própria versão.

Ainda sobre as traduções brasileiras de Barthes, aqui usamos as versões de seus mais estabelecidos estudiosos, e quando as obras referenciadas eram inéditas em português ou não se encontravam no rol de seus estudiosos consagrados, optamos por tradução livre, devidamente indicada. E o mesmo vale para as obras de Nietzsche, Derrida e Deleuze.

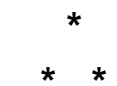

Sob muitos aspectos, é difícil de se imaginar uma voz crítica mais substancialmente francesa que a de Roland Barthes. Do início dos anos 1950 em diante, o enfoque de seus trabalhos publicados permaneceu sendo literatura e cultura francesas. Além de livros sobre Michelet, Racine, Balzac e Sollers, Barthes também dedicou ensaios a uma ampla gama de escritores franceses, incluindo La Rochefoucauld, La Bruyère, Diderot, Sade, Chateaubriand, Fourier, Stendhal, Flaubert, Baudelaire, Proust, Bataille e Robbe-Grillet. Em discrepante comparação, não há ensaios publicados que tenham sido inteiramente dedicados a nenhum escritor de língua inglesa, e relativamente poucos sobre as obras de escritores não franceses-europeus. A esse perfil poderia ser adicionada a incontestável apreciação francesa de Barthes pela cultura japonesa, refletida mais notavelmente no Império dos signos (1970), bem como o fato de que as suas principais alternâncias metodológicas, de crítica ideológica de inspiração marxista ao estruturalismo, ao pós-estruturalismo, foram moldadas em medida nada pequena por intervenções dentro do discurso literário filosófico francês, de Saussure a Lacan, a Deleuze, a então Derrida.

Esses limites linguísticos-nacionais nos interesses críticos de Barthes estão também refletidos em sua assumida falta de competência em qualquer língua estrangeira. Como crítico cuja atenção era direcionada acima de tudo pelos meios com que textos significam - isso é, pelas questões de estilo, código, e sistema - talvez não seja surpreendente que, em suas análises de literatura, Barthes devesse ter se restringido em larga escala a obras originalmente escritas na única língua em que se sentia à vontade. De fato, como o próprio Barthes colocou tão tardiamente em 1979: "je n'aime vraiment que ce qui est écrit en français." Essa limitação linguística torna ainda mais

\footnotetext{
${ }^{3}$ Roland Barthes, "Roland Barthes s'explique" (1979), em CEuvres complètes, 3 vols, ed. por Éric Marty (Paris: Seuil, 1995), III, 1068-79 (p.1077). N.T.: "eu amo verdadeiramente apenas o que está escrito em francês." (tradução nossa).
} 
significante suas duas exceções, as quais apontam ambas para o profundo impacto (ainda que por tradução e de forma parcialmente mediada) de duas vozes muito diferentes da cultura alemã.

Quase ao fim de sua admirável obra (auto) biográfica Roland Barthes por Roland Barthes (1975), Barthes divide sua vida escritural em cinco "fases", cuja primeira é caracterizada apenas pelo desejo de escrever. Quanto às outras quatro, ele identifica um "intertexto", um "gênero", e as maiores obras publicadas que pertencem a essa fase. ${ }^{4}$ Salvo três exceções, os intertextos em questão são todos francófonos: Gide na primeira fase; Sartre na segunda; Saussure na terceira; e Sollers, Kristeva, Derrida, e Lacan na quarta. As exceções são Marx e Brecht (junto de Sartre) na segunda fase, e Nietzsche como o único intertexto na quinta. Na fase moldada pelo impacto de Marx e Brecht, o gênero correspondente é identificado como "mitologia social", e as obras escritas nesse gênero como O grau zero da escrita (1953), Mitologias (1957), e os ensaios sobre teatro. No entanto, seria justo dizermos que a influência de Brecht se estende muito além dessa segunda fase à medida que a ideia central de um "efeito de alienação" (Verfremdungseffekt) do teórico alemão dramaturgo claramente tem um papel decisivo na formação das noções de desnaturalização crítica e desmitificação do próprio Barthes. Em sua continuada crítica do mito, doxa, e estereótipos, e seu persistente comprometimento em expor o aparentemente natural como cultural, ou, mais precisamente, ideologicamente construído, Brecht, o teórico, permaneceu uma persistente pedra de toque para Barthes.

Quanto ao outro intertexto alemão - o qual Barthes via como sua atual e, como se provaria, fase final - o nome de Nietzsche é colocado entre parênteses na tabela de Barthes, assim como o de Gide, cujo romance $O$ Imoralista (1902) foi sem dúvida uma das primeiras fontes nas quais se mostraria dar seu encontro altamente mediado com o pensamento de Nietzsche. Apesar de glosar os termos "intertexto" e "gênero", Barthes não explica por que escolhera colocar os nomes Gide e Nietzsche entre parênteses. Parece-se claro, contudo, que alguma tentativa de distanciamento ou limitação está tomando lugar aqui - no caso de Nietzsche, essa limitação é em grande parte devida ao fato de que o encontro de Barthes com a obra do filósofo alemão não era apenas por tradução, mas também em larga escala por via de obras de outros pensadores franceses sobre Nietzsche. Se há de fato uma tal tentativa de se distanciar ou limitar o intertexto Nietzsche aqui, não está menos comprometido o fato de que o próprio pensamento de intertexto de Barthes na metade dos anos 1970 é ele

\footnotetext{
${ }^{4}$ Versão brasileira: Barthes, Roland Barthes por Roland Barthes. Tradução de Leyla PerroneMoisés. São Paulo: Estação Liberdade, 2003. (p. 162).
} 


\section{Criação \&}

mesmo profundamente nietzschiano na ênfase que se dá à metáfora. Um intertexto é, Barthes insiste, não forçosamente um "champ d'influences"; é antes uma "musique de figures, de métaphores, de pensées-mots". ${ }^{5}$ Junto à ênfase sobre o musical e o metafórico, a afirmação de Barthes de que "moralité" é o gênero ao qual pertencem obras como O Prazer do texto (1973) e Roland Barthes por Roland Barthes apenas reforça o papel decisivo exercido pelo pensamento de Nietzsche na concepção de Barthes dessa fase de sua vida escritural. Em Roland Barthes, ele nota que sua concepção de moralidade é na verdade a própria antítese do que normalmente se entende por moralidade; pois é "la pensée du corps en état de langage". ${ }^{6}$ Moralidade, nesse sentido nietzschiano, deve ser entendida como o que Nietzsche designa "I'expression corporelle". ${ }^{7}$ Pensar moralidade desse modo, como corpo tendo se tornado linguagem, portanto, claramente deve muito à própria ideia de Nietzsche do corpo e de sua íntima, não-cartesiana, relação com o pensamento. ${ }^{8}$

De acordo com Philippe Sollers, que o conhecia bem, Barthes fora um "lecteur de Nietzsche, comme peu l'auront été, toute sa vie!", acrescenta a respeito do ensaio de Barthes sobre seu próprio romance $H$ (1973): "Nietzsche, très souvent. Les citations de Nietzsche sont toujours là." ${ }^{9}$ Referências a Nietzsche e citações dele devem ser encontradas, entretanto, predominantemente nas obras de Barthes dos anos 1970, alcançando sua maior extensão nos seminários no Collège de France apresentados entre

\footnotetext{
${ }^{5}$ Versão brasileira: Barthes, Roland Barthes por Roland Barthes. p. 162. Em seu seminário de 1973-74 na École pratique des hautes études sobre "Le Lexique de l'auteur", Barthes afirma que uma escrita de "palavras-valises" não deve ser confundida com um estilo, e que, dentre os filósofos, apenas Nietzsche alcançou tal escrita. Cf. Barthes, Le Lexique de l'auteur: séminaire à l'École pratique des hautes études 1973-1974. Suivi de fragments inédits du 'Roland Barthes par Roland Barthes', ed. por Anne Herschberg Pierrot (Paris: Seuil, 2010), pp. 62 e 129. N.T.: "campo de influências" (...) "música de figuras, de metáforas, de pensamentos-palavras". Tradução de Leyla Perrone-Moisés em Roland Barthes por Roland Barthes. São Paulo: Estação Liberdade, 2003. (p. 162).

${ }^{6}$ Versão brasileira: Barthes, Roland Barthes por Roland Barthes. p. 162. N.T.: "moralidade"; "o pensamento do corpo em estado de linguagem". Tradução de Leyla Perrone-Moisés em Roland Barthes por Roland Barthes. São Paulo: Estação Liberdade, 2003. (p. 162).

${ }^{7}$ Barthes, Le Lexique de l'auteur, p. 59; grifo original. Barthes está citando aqui de uma nota de Nietzsche inclusa na Vontade de Potência. "Considero a moralidade grega (...) como a mais elevada que já se criou; o que me prova isso é que ela levou ao seu ápice a expressão corporal. Mas a moralidade na qual penso é a moralidade efetiva do povo, não a dos filósofos" (Nietzsche, citado em ibid., pp. 59-60). N.T.: expressão corporal. (tradução nossa). ${ }^{8} \mathrm{Em}$ La Préparation du roman, Barthes declara que vê as coisas exatamente do jeito que elas são vistas no Ecce Homo de Nietzsche, isso é, em relação a "escolha do corpo"; Barthes, La Préparation du roman cours au Collège de France 1978-1979 et 1979-1980, ed. por Nathalie Léger (Paris: Seuil, 2015). N.T.: as notas de aula de La Préparation du roman não têm versão brasileira, mas pode-se encontrar tal referência na aula de 26 de janeiro de 1980, ao final do capítulo "Maison", da obra supracitada.

${ }^{9}$ Philippe Sollers, L'Amitié de Roland Barthes (Paris: Seuil, 2015), pp. 26 and 30. N.T.: "leitor de Nietzsche como poucos foram, por toda sua vida!" (...) "Nietzsche, com muita frequência. As citações de Nietzsche estão sempre lá." (tradução nossa).
} 
1976 e a morte prematura de Barthes, na primavera de $1980 .{ }^{10}$ Além de suas concepções de intertexto e moralidade, Barthes vai, no curso dos anos 1970, empregar um grande número de topoi nietzschianos em sua obra. Como veremos, esses topoi têm um papel decisivo na emergência da concepção de Barthes - e sobretudo em sua prática - daquilo que (tomando o termo de um trabalho sobre, ao invés de por Nietzsche) ele descreve como uma "filologia ativa".

Os topoi nietzschianos que são assumidos por Barthes nos anos 1970 incluem a ideia de modernidade como sendo principalmente caracterizada por uma "crise da verdade" e por um niilista "achatamento dos valores"; a convicção de que todos os conceitos são metáforas, de que não há fatos, apenas interpretações; ${ }^{11}$ de que o conhecimento é irredutivelmente perspectivo, de que a subjetividade é descontinuada; e de que a luta determinante da modernidade é entre o artista e o sacerdote, o primeiro contra o rebanho (isso é, contra todas as formas de doxa, e contra todos os fatos morais fornecidos pelo sacerdote). ${ }^{12}$ Pois para esse artista nietzschiano, pathos e dramatização são centrais para uma justificação estética que suplantaria qualquer justificação moral disso. ${ }^{13}$ Talvez a declaração mais dramática na obra de Barthes a respeito desse comprometimento nietzschiano com o pathos e a dramatização venha perto do fim de $A$ câmara clara (1980), quando Barthes faz uma observação acerca de sua relação afetiva com os fotógrafos pelos os quais ele havia sido "pungido". Ele confessa:

[J]'entrais follement dans le spectacle, dans l'image, entourant de mes bras ce qui est mort, ce qui va mourir, comme le fit

\footnotetext{
${ }^{10}$ Como Sollers, Anne Herschberg afirma que Barthes estaria lendo Nietzsche "há muito tempo"; contudo, ela acrescenta a importante qualificação que, em suas notas para esse seminário, "Le Lexique de l'auteur", Barthes cita da então recentemente publicada antologia Vie et vérité, ed. por Jean Garnier (Paris: Presses universitaires de France, 1971). Cf. Anne Herschberg, "Présentation" em Barthes, Le Lexique de l'auteur, pp.23-39 (p.24).

${ }^{11} \mathrm{Em}$ um fragmento intitulado "Déjouer" em seu ensaio sobre Le Gros Orteil, Barthes cita Nietzsche quando esclarece que quando o conhecimento é "émietté" (N.T.: esmigalhado), isso implica não em sua destruição, mas em seu deslocamento. N.T.: cf. na versão brasileira e traduzida por Mario Laranjeira, o fragmento referenciado se chama "Eludir" e está no capítulo "As saídas do texto" em O rumor da língua. São Paulo: WMF Martins Fontes, 2012; p. 304.

${ }^{12} \mathrm{Em}$ um texto tardio sobre o cineasta italiano Michelangelo Antonioni, Barthes identifica as três "virtudes" do artista, enquanto distintas do sacerdote, como "a vigilância", "a sabedoria, e "a fragilidade"; Barthes, "Cher Antonioni..." (1980), em CEuvres complètes, ed. por Marty, III, 1208-12 (p. 1208). Aqui, como tão frequentemente nos anos 1970, Barthes se refere explicitamente a Nietzsche ao fazer a distinção entre o artista e o sacerdote, articulada de modo mais completo no terceiro ensaio de Para uma genealogia da moral (1887), "O que significam os ideais ascéticos?". Lucy O'Meara destaca a importância de um número desses topoi na obra tardia de Barthes: O'Meara, Roland Barthes at the Collège de France (Liverpool: Liverpool University Press, 2012), especialmente "Aula e 'Durante muito tempo, fui dormir cedo"', pp. 52-86.

${ }_{13}$ Versão brasileira: Nietzsche, O nascimento da tragédia, p. 40. Tradução de Paulo César de Souza. São Paulo: Companhia de Bolso, 2020.
} 


\section{Criação \&}

Nietzsche, lorsque, le 3 janvier 1889, il se jeta en pleurant au cou d'un cheval martyrisé: devenu fou pour cause de Pitié. ${ }^{14}$

Um exemplo mais antigo e sustentado da dramatização inspirada em Nietzsche é a decisão de Barthes de assumir o papel do amante nos Fragmentos de um discurso amoroso (1977). Barthes reconhece a "influência" de Nietzsche a respeito disso, acrescentando que fora a insistência de Nietzsche sobre a "dramatização" como um método que o possibilitou de se libertar de qualquer dependência de uma metalinguagem que situaria a voz crítica acima e além do pessoal, do corporal, e do perspectivo. ${ }^{15}$ Assim, a dramatização nietzschiana é em parte uma estratégia elaborada para libertar Barthes da persuasão do científico. Um efeito similar é alcançado pelo comprometimento de Barthes com o "pour moi" nietzschiano, o qual tem um "valeur fondatrice" para ele dentro do "asystème" ou do "système ouvert" da valoração nietzschiana. ${ }^{16}$

Se Nietzsche é o grande filósofo diagnosticador da crise da verdade na modernidade, Barthes encontra o engajamento literário mais aguçado dessa crise na obra de Flaubert, acima de tudo na publicação póstuma de Bouvard et Pécuchet (1881). Essa crise é em seu mais profundo nível uma forma de ceticismo da linguagem, no qual, como coloca Barthes em 1976: "C'est le moment où on s'aperçoit que le langage ne présente aucune garantie"; com a perda da garantia linguística, é "la crise de la modernité qui s'ouvre". ${ }^{17}$ Portanto, a análise de Barthes da modernidade se dá no interior de uma tradição de linguagem cética moderna que aparece na segunda metade do século dezenove, das mais sustentadas expressões filosóficas sobre as quais no fim do dezenove e no começo do século vinte são publicados os ensaios póstumos de Nietzsche "Sobre a verdade e a mentira

\footnotetext{
${ }^{14}$ N.T.: “(...) entrava [eu] loucamente no espetáculo, na imagem, envolvendo com meus braços o que está morto, o que vai morrer, tal como fez Nietzsche, quando a 3 de janeiro de 1889 lançou-se a chorar ao pescoço de um cavalo martirizado: enlouquecido por causa da Piedade." Versão brasileira: Barthes, A câmara clara; tradução de Júlio Castañon Guimarāes. Rio de Janeiro: Nova Fronteira, 2015. (p. 97). Alguns anos antes, em 1977, quando procurava defender a obra de Deleuze em resposta à crítica de Bernard-Henri Lévy, Barthes esclarece que seu próprio pensamento de pathos é nietzschiano de ponta a ponta, e que, para ele, como para Nietzsche, a própria linguagem é uma "paixão" ou um "pathos" no sentido de um "pathos das distâncias"; Barthes, 'Lettre à Bernard-Henri Lévy', in CEuvres complètes, ed. por Marty, III, 703-04 (p. 703). Em La Préparation du roman, Barthes dá sua própria definição inspirada em Nietzsche de "pathos, isso é, tudo que é "da ordem do afeto" (Barthes, La Préparation, p. 125); N.T.: notas de aula do dia 16 de dezembro de 1978.

${ }^{15}$ Barthes, "Entretien" (1977), em CEuvres complètes, ed. por Marty, III, 774-79 (p. 776).

${ }^{16}$ Barthes, Le Lexique de l'auteur, p. 45. N.T.: "para mim"; "valor fundador"; "asistema"; "sistema aberto" (tradução nossa).

${ }^{17}$ Barthes, "La Crise de la modernité" (1976), em CEuvres complètes, ed. por Marty, III, 43437 (p. 435). N.T.: "É o momento em que se percebe que a linguagem não presta nenhuma garantia"; "a crise da modernidade que se inicia". (tradução nossa).
} 


\section{Criação \&}

no sentido extramoral" (escrito em 1873; primeiramente publicado em 1903), e os três volumes das Contribuições para uma Crítica da Linguagem (1901-02). ${ }^{18}$

Em seu seminário de 1977-78 sobre O Neutro, Barthes afirma que foi Nietzsche quem "a mieux démonté (dans le deux sens du terme) le concept". ${ }^{19} \mathrm{O}$ argumento de um desmonte de conceitos de Barthes aqui retoma, em seu nominalismo, o de Hugo von Hofmannthal's Lord Chandos em A Carta de Lord Chandos (1902). O conceito deve, Barthes sustenta, ser desmontado porque, em sua abstração, nega-se a diferença, reduzindo singularidades a generalidades. Quanto ao que leva a tal desmonte de conceitos, Barthes toma um partido decididamente nietzschiano (e, como acontece, mauthneriano), a saber, que conceitos precisam ser expostos como metáforas, e que eles nunca simplesmente refletem ou delineiam uma realidade dada de antemão, extralinguística. Como Barthes argumenta em $O$ Neutro, escrever é "dire non au concept" (ibid., versão brasileira, p. 324. N.T.: "dizer não ao conceito"), com essa negação tomando a forma de uma substituição do conceito pela metáfora. Nessa definição de escrever, Barthes ecoa nos termos mais claros a celebrada reivindicação nietzschiana de que a verdade não é senão um "batalhão móvel de metáforas". ${ }^{20}$

Para Barthes, Nietzsche é imprescindível para um entendimento da modernidade porque, acima de tudo, ele reconhece o papel determinante exercido pela linguagem na construção da realidade humana, e, de fato, que os ditos fatos não são senão construções linguísticas. A declaração chave aqui é a reivindicação de que não há fatos, apenas interpretações. ${ }^{21}$ Citando tal afirmação em 1967, Barthes continua a insistir que os ditos fatos são sempre precisamente isso: ditos. Fatos sempre têm, necessariamente, apenas uma "existência linguística"; porém, em um paradoxo do qual não podemos nunca nos desenredar completamente, "tout se passe comme si

\footnotetext{
${ }^{18}$ Para um panorama informativo dessa crise da linguagem, cf. George Steiner, "The Retreat from the Word", em Language and Silence (London: Faber \& Faber, 1967), pp. 30-54; e Real Presences: Is There Anything in What We Say? (London: Faber \& Faber, 1989). Cf. também, 'Modernism and Language Scepticism', em The Bloomsbury Companion to Modernist Literature, ed. por Ulrika Mauder Mark Nixon (London: Bloomsbury Academic, 2018), pp. 63-79.

${ }^{19}$ Versão brasileira: Barthes, O Neutro. Tradução de Ivone Castilho Benedetti. São Paulo: Martins Fontes, 2003; p. 323. N.T.: "melhor desmontou (nos dois sentidos do termo) o conceito". Em nota de rodapé, a tradutora acrescenta: "[Oral: "como se explicita um mecanismo e como se apeia um cavaleiro", acrescenta Barthes.]"

${ }^{20}$ Versão brasileira: Nietzsche, "Sobre verdade e mentira no sentido extramoral", Obras incompletas / Friedrich Nietzsche. Tradução de Rubens Rodrigues Torres Filho. São Paulo: ed. 34, 2014. (p. 66).

21 "Contra o positivismo que para no fenômeno - "Há apenas fatos" - Eu diria: não, fatos é justamente o que eles não são, eles são apenas interpretações"; Nietzsche, Writings from the Late Notebooks, ed. by Rüdiger Bittner, trans. by Kate Sturge (Cambridge: Cambridge University Press, 2003), 'Notebook 7, end of 1886 - spring 1887', p. 139. N.T.: tradução nossa da obra supracitada em inglês.
} 


\section{Criação \&}

cette existence n'était que la 'copie' pure et simple d'une autre existence, située dans un champ extra-structural, le 'réel'". ${ }^{22}$ Para Barthes, novamente ecoando Nietzsche, o que se segue desse insight na natureza linguística pura dos fatos é que não se pode haver uma interpretação definitiva. Em vez disso, há uma irredutível pluralidade de interpretações: nisso reside o pluralismo de Nietzsche. Não há fatos absolutos nem verdades absolutas a serem desenterrados e comunicados. Ao invés disso, as interpretações competem umas com as outras, e, para Nietzsche, devem ser julgadas não ao passo que correspondem a uma realidade pré-interpretativa, mas sim ao passo que expressam uma vontade de potência em sua forma mais ativa (ao invés de reativa). ${ }^{23}$

Quanto à distinção entre forças ativas e reativas, Barthes se envolve completamente com a preocupação primordial de Nietzsche em sua obra no fim dos anos 1880, a saber, o diagnóstico do "niilismo europeu" e a concepção de como esse niilismo poderia ser superado. A concepção de Nietzsche da modernidade como a culminação de um niilismo que tem suas fontes pares na filosofia socrática e na cristandade paulina é central para a própria concepção de Barthes da era moderna como caracterizada por uma desvalorização radical. Como Barthes coloca em 1973, em um ensaio sobre Georges Bataille, cuja própria obra foi moldada em seu cerne pela sua leitura de Nietzsche: ao invés de simplesmente destruir o valor, a burguesia "l' aplatit, la rapetisse, fonde un système du mesquin". ${ }^{24}$ Seguindo Nietzsche, e como muitos outros intelectuais franceses do final dos séculos dezenove e vinte, Barthes identifica "la petite bourgeoisie" como a fonte de muito, senão de tudo aquilo que deve ser submetido à crítica. Como George Orwell nos anos

\footnotetext{
22 Versão brasileira: Barthes em "O discurso da história", O rumor da língua. Tradução de Mario Laranjeira. São Paulo: WMF Martins Fontes, 2012; p. 177. N.T.: "tudo se passa como se essa existência não fosse senão a 'cópia' pura e simples de uma outra existência, situada num campo extra-estrutural, o 'real'".

${ }^{23}$ Barthes faz referência apenas raramente ao conceito de vontade de potência, e quando o faz, é geralmente por meio de Deleuze, que, em Nietzsche e a filosofia, dedica considerável atenção para libertar o conceito de uma interpretação daquilo que encontrou sua mais extrema manifestação na concepção nazista da filosofia de Nietzche; cf. versão brasileira de Nietzsche e a filosofia, "Ativo e reativo", p. 55. São Paulo: n-1 edições, 2018. Em O Neutro, por exemplo, Barthes afirma que Nietzsche "não é diretamente um 'filósofo' do conflito", citando Deleuze para apoiar seu ponto de vista: "As noções de luta, de guerra, de rivalidade ou mesmo de comparação são estranhas a Nietzsche e à sua concepção de vontade de poder." Versão brasileira: Tradução de Ivone Castilho Benedetti. O Neutro. São Paulo: Martins Fontes, 2003; p. 260.

${ }^{24}$ Versão brasileira: Barthes em "As saídas do texto", O rumor da língua. Tradução de Mario Laranjeira. São Paulo: WMF Martins Fontes, 2012; p.301. N.T.: "achata-o, apouca-o, funda um sistema do mesquinho"; grifo original.
} 


\section{Criação \&}

entre guerras, Barthes considera essa classe "dangereuse" pois "elle a toujours fini par se rallier aux régimes forts et fascists". ${ }^{25}$

Barthes assume a defesa de Nietzsche do aristocrático e do nobre como a única força combatente viável contra a petite bourgeoisie, argumentando em $O$ Neutro que um dos signos característicos da aristocracia é a "apathie", enquanto "ce serait (thème nietzschéen) le 'grégaire', le 'réactif' (les faibles, les prêtres, les hommes du ressentiment) qui serait 'activiste"'. ${ }^{26}$ Não apenas aqui é a distinção de Barthes entre forças ativas e reativas retirada de Nietzsche, junto daquela do rebanho - ou "le grégaire" 27 - mas também o é a distinção entre artista e sacerdote, e de fato a própria concepção de Barthes de valor como tal. Como Barthes explica em seu ensaio sobre Bataille, quando ele emprega o termo "valeur", esse deve ser entendido em "un sens nietzschéen"; a saber, como "la fatalité d'un paradigm intraitable: noble/vil'. ${ }^{28}$

Para Nietzsche, o enfrentamento do niilismo concebido como uma desvalorização absoluta deve ser alcançado por um comprometimento com as forças ativas (como oposta às reativas ou, de fato, "ativistas"), encarnadas na figura do Übermensch. Significantemente, entretanto, as referências de Barthes a essa figura são raras. Ao invés do Übermensch, e da alcançada superação do niilismo, a atenção de Barthes se concentra, pelo contrário, na culminação do niilismo. Desse modo, por exemplo, ele identifica o hippie como uma das potenciais contemporâneas "pré-figures du sur-homme, celle que Nietzsche assignait au nihiliste dernier, celui qui tente de généraliser et de pousser la valeur reactive au point d'empêcher qu'elle soit récupérée par quelque positivité". ${ }^{29}$ Essa atração pela figura do "último niilista" reside no

\footnotetext{
${ }^{25}$ Barthes, "Des mots pour faire entendre un doute" (1978), em CEuvres complètes, ed. por Marty, III, 919-23 (p. 920). N.T.: "a pequena burguesia"; "perigosa"; "ela sempre terminou por se aliar aos regimes fortes e facistas". (tradução nossa).

${ }^{26}$ Versão brasileira: Barthes, O Neutro. Tradução de Ivone Castilho Benedetti. São Paulo: Martins Fontes, 2003; p. 377. N.T.: "apatia"; "seriam (tema nietzschiano) o 'gregário', o 'reativo' (os fracos, os padres, os homens do ressentimento) os 'ativistas'".

${ }^{27} \mathrm{Em} 1973$, Barthes observou que "[l]e phénomène historique qui a l'air de se dévoiler comme ça depuis dix ans, c'est le problème de la 'grégarité' - c'est un mot nietzschéen. Les marginaux se multiplient, se rassemblent, deviennent des troupeaux"; Barthes, "La Crise du désir" (1973), em CEuvres complètes, ed. por Marty, III, 1243-46 (p. 1244). N.T.: "o fenômeno histórico que parece se desvelar assim há dez anos é o problema da 'gregariedade' - uma palavra nietzschiana. Os marginais se multiplicam, juntam-se, tornam-se tropas". (tradução nossa).

${ }^{28}$ Versão brasileira: Barthes em "As saídas do texto", O rumor da língua. Tradução de Mario Laranjeira. São Paulo: WMF Martins Fontes, 2012; p. 308-9. N.T.: (...) "valor"; "um sentido nietzschiano"; "a fatalidade de um paradigma intratável: nobre/vil".

${ }^{29}$ Barthes, "Un cas de critique culturelle" (1969), em CEuvres complètes, ed. por Marty, II, 544-46 (p. 545). N.T.: "pré-figuras do além-do-homem, a que Nietzsche atribuia ao último niilista, aquele que tenta generalizar e forçar o valor reativo a ponto de impedir que ele seja recuperado por alguma positividade". (tradução nossa).
} 


\section{Criação \&}

bojo da concepção de Barthes inspirada em Nietzsche da natureza e propósito da crítica, e no bojo de sua prática de filologia ativa no final dos anos 1970.

Não obstante a afirmação de Sollers de que Barthes fora um "lecteur de Nietzsche, comme peu l'auront été", os textos de Nietzsche aos quais Barthes faz referência nos anos 1970 estão principalmente restritos a duas obras tardias, Para a genealogia da moral (1887) e Ecce homo (1888), ${ }^{30}$ bem como à seleção de notas postumamente publicadas que foram apresentadas (enganosamente) por seus editores originais sob o título de Vontade de Potência (1901). Não menos importante, como fica particularmente claro nas notas de aula do Collège de France, o Nietzsche de Barthes era altamente mediado. Tem-se geralmente assumido que o principal mediador do pensamento de Nietzsche para Barthes tenha sido Gilles Deleuze, cujo Nietzsche e a filosofia (1962) ele reconhece ter lido "bien après" de ter sido publicado, ${ }^{31}$ e ao qual ele se refere em várias ocasiões em seus seminários do Collège de France. Entretanto, à medida que o texto de Deleuze lhe serviu como um inestimável guia para o pensamento de Nietzsche, há muito na concepção de Nietzsche de Deleuze que não tem lugar na obra de Barthes em nenhuma extensão significante, e Barthes se afasta da posição de Deleuze de Nietzsche como o grande pensador da superação do niilismo. O principal objetivo de Deleuze em Nietzsche e a filosofia é apresentar Nietzsche como um contra-filósofo de Hegel; isso é, como um pensador não dialético que, em contraste com Hegel, dá ao negativo um papel subordinado. O Nietzsche de Deleuze é, em suma, o filósofo do devir, do eterno retorno, e da superação do niilismo. O Nietzsche de Barthes é algo bem diferente: ele é o pensador da verdade como metáfora, do jogo e do escrever como uma "expression corporelle".

Em certos aspectos chave, o Nietzsche de Barthes carrega uma afinidade muito maior com o de Derrida do que com o de Deleuze. O texto decisivo a esse respeito é o ensaio de Derrida "La Structure, le signe et le jeu dans le discours des sciences humaines", primeiramente apresentado em 21 de outubro de 1966 em um colóquio internacional sobre "Les Langages critiques et les sciences de l'homme", sediado na Universidade John Hopkins,

\footnotetext{
${ }^{30}$ Referências à "autobiografia" de Nietzsche, Ecce Homo, são particularmente frequentes no último seminário de Barthes no Collège de France, $A$ Preparação do romance, e a obra está inclusa na lista de leitura do curso.

${ }^{31}$ Barthes, "À quoi sert un intellectuel?" (1977), em CEuvres complètes, ed. por Marty, III, 746-60 (p. 757). É difícil datar com real precisão a leitura de Barthes de Nietzsche e a filosofia. Dito isso, o interesse de Barthes por Nietzsche, como é evidente através das referências à sua obra, certamente se intensifica no final dos anos 1960, em seguida da publicação de Derrida $A$ Escritura e a diferença (Paris: Seuil, 1967). Outra obra de Nietzsche à qual Barthes se refere nos anos 1970, embora com muito menos frequência se comparado ao texto de Deleuze, é Nietzsche e o círculo vicioso de Pierre Klossowsli (Paris: Mercure de France, 1969).
} 


\section{Criação \&}

um evento em que Barthes também falou. ${ }^{32}$ Derrida conclui esse influente ensaio, em que ele desafia todo o projeto estruturalista com o qual Barthes esteve engajado nos anos 1960, com um contraste entre Rousseau e Nietzsche, dando ênfase diretamente à ideia de jogo e ao que Derrida vê como a "affirmation d'un monde de signes sans faute, sans vérité, sans origine, offert à une interprétation active" ${ }^{33}$ de Nietzsche. Por volta de 1970, Barthes estava pronto para reconhecer que ele era "tout à fait pour" (N.T.: "totalmente favorável à") noção de jogo $^{34}$ e que ele continuaria ao longo daquela década a desenvolver a ideia de uma crítica enquanto, acima de tudo, um modo de "déjouer" (N.T. "eludir") essas formas de pensamento que buscam estabelecer um sentido (ou sentidos) estável, uma verdade como outra coisa que não uma função textual ou uma metáfora, e qualquer tipo de metalinguagem. Para Barthes, o desafio era "déjouer le refoulé" (N.T.: "eludir o recalcado"), com essa derrota ou desconcerto precisamente não sendo uma tentativa de "le faire exploser". (N.T.: "fazê-lo explodir"). ${ }^{35}$ Nesse comprometimento com a derrota ou desconcerto do significado, Barthes abandona a ideia da crítica como ciência - isso é, de uma semiologia inspirada em Saussure com o poder de estabelecer verdade e conhecimento. No lugar de uma tal ciência, Barthes se compromete com o que Derrida, evocando Nietzsche, descreve como uma interpretação ativa.

O próprio termo de Barthes para essa interpretação ativa (em contraposição à reativa) inspirada em Nietzsche é "filologia ativa". É em seu seminário de 1976-77, Como viver junto, que Barthes finalmente identifica sua própria prática crítica como uma forma de filologia ativa:

D'une façon générale, je suis persuadé que le rapport du mot au référent n'est pas réductible une fois pour toutes à un schème universel. Le sujet, lecteur, auditeur, a un rapport différentiel aux mots en fonction de leurs référents. Ce serait là une voie de recherche de la philologie active, voulue par

\footnotetext{
$32 \mathrm{O}$ ensaio de Derrida foi publicado no ano seguinte em $A$ Escritura e a diferença. A contribuição de Barthes para o colóquio foi "Écrire, verbe intransitive?" (em CEuvres complètes, ed. por Marty, II, 973-80).

${ }_{33}$ Derrida, A Escritura e a diferença. Tradução de Maria Beatriz Marques Nizza da Silva. São Paulo: Editora Perspectiva. $2^{\mathrm{a}}$ edição. (p. 248). N.T.: "afirmação de um mundo de signos sem erro, sem verdade, sem origem, oferecido a uma interpretação ativa".

${ }^{34}$ Barthes, "L’Express" va plus loin avec... Roland Barthes" (1970), em CEuvres complètes, ed. por Marty, II, 1017-30 (p. 1028).

${ }^{35}$ Barthes, "Entretien (A Conversation with Stephen Heath)" (1971), em CEuvres complètes, ed. por Marty, II, 1291-1306 (p. 1303). Alhures, citando Nietzsche sobre o "homme moyen" (N.T.: "homem médio"), Barthes declara que ele procura deixar o significado "boiteux" (N.T.: "coxo"), e precisamente não destrui-lo. (Versão brasileira: Barthes em "As saídas do texto", $O$ rumor da língua. Tradução de Mario Laranjeira. São Paulo: WMF Martins Fontes, 2012; p. 310).
} 


\section{Criação \&}

Nietzsche: philologie des forces, des différences, des intensités. ${ }^{36}$

Isso pede por uma filologia ativa recorrente ao final da segunda aula do seminário de Barthes sobre o "Discours-Charlus" em Em busca do tempo perdido de Proust, apresentado em 30 de março de 1977, em que Barthes oferece uma definição bem diferente da prática: "la Nouvelle Philologie, ou Philologie active, que voulait Nietzsche: "philologie du qui et non du quor". ${ }^{37}$ Essa definição está de acordo com as observações de Barthes sobre o "pour moi" em seu seminário sobre o "Le Lexique de l'auteur", ${ }^{38}$ e com o livro que resultou desse seminário: Roland Barthes por Roland Barthes.

Apesar de Nietzsche fazer várias observações sobre filologia em seus trabalhos publicados em vida e em várias notas que foram postumamente publicadas sob o título de Vontade de Potência, ele não se refere explicitamente em nenhum lugar a uma "filologia ativa". Na verdade, a fonte dessa concepção de sua própria prática crítica não é Nietzsche, mas Deleuze tratando de Nietzsche. É na seção I ("Transformações das ciências do homem") do capítulo sobre "A Crítica" em Nietzsche e a filosofia que Deleuze faz referência a uma filologia ativa: "Nietzsche rêve d'une autre philologie, une philologie active". Deleuze então prossegue para esclarecer o que deve ser entendido por tal filologia:

La philologie active de Nietzsche n'a qu'un principe: un mot ne veut dire quelque chose que dans la mesure ou celui qui le dit veut quelque chose en le disant. Et une seule règle: traiter la parole comme une activité réelle, se mettre au point de vue de celui qui parle. (...) La linguistique active cherche à découvrir celui qui parle et qui nomme. ${ }^{39}$

\footnotetext{
${ }^{36}$ Barthes, Comment vivre ensemble: simulations romanesques de quelques espaces quotidiens. Notes de cours et de séminaires au Collège de France, 1976-1977, ed. por Claude Coste (Paris: Seuil/IMEC, 2002), p. 149. Em um fragmento sobre filologia que no final das contas não foi incluído em Roland Barthes, Barthes fornece uma concepção emergente de si mesmo enquanto filólogo: "Il aime le langage, il aime le texte [...]; en somme, c'est, à la lettre, un philologue (et même, peut-être, pire: un phraséologue)"; Barthes, Le Lexique de l'auteur, p. 322. (N.T.: "Ele ama a linguagem, ele ama o texto (...); em suma, isso é, ao pé da letra, um filólogo (e talvez mesmo pior: um fraseólogo)". (tradução nossa).

${ }^{37}$ Versão brasileira: Barthes, Como viver junto. Tradução de Leyla Perrone-Moisés. São Paulo: Martins Fontes, 2003; p.328. N.T.: "da Nova Filologia ou Filologia ativa, desejada por Nietzsche: filologia do quem e não do quê." (grifo original). Para uma análise da leitura de Barthes de "Discours-Charlus", cf. Thomas Baldwin, "Charlus/z", Nottingham French Studies, 53 (2014), 90-101.

${ }^{38}$ Cf. Barthes, Le Lexique de l'auteur, pp. 45-50.

${ }^{39}$ Versão brasileira: Deleuze, Nietzsche e a filosofia. Tradução de Marina de Toledo Barbosa e Ovídio de Abreu Filho. São Paulo: n-1 edições, 2018; p.98. N.T.: "Nietzsche sonha com uma outra filologia, uma filologia ativa"; "A filologia ativa de Nietzsche só tem um princípio:
} 


\section{Críticão \&}

É precisamente esse princípio do "quem" que é assumido por Barthes em Como viver junto: "philologie du qui et non du quoi". Quanto à outra definição de Barthes de filologia ativa - isso é, como filologia das forças, diferenças e intensidades - a terminologia é claramente deleuziana.

Malgrado essas duas tentativas de definição, a concepção de Barthes de filologia ativa é, antes e acima de tudo, uma crítica prática que pode ser compreendida como uma forma de niilismo ativo com certa proximidade de Gianni Vattimo. ${ }^{40}$ Seu propósito é debilitar o pensamento fundamentador, pelo qual se deve entender um pensamento em termos de verdade, conhecimento e origem. E se isso é uma forma de hermenêutica, então é um propósito pelo qual não se deve estabelecer o significado ou significados de um texto, nem mesmo uma "ouverture absolue du sens", um tipo de hermenêutica em que tudo passa, mas sim o que Barthes denomina "des exemptions de sens, des suppressions, des annulations de sens". ${ }^{41}$

É nesse cancelamento do sentido que o nilismo da filologia ativa reside. Que Barthes concebe o que ele viria a chamar de "filologia ativa" como uma forma de niilismo é evidente a partir de sua observação em 1971 que se deveria "lire le texte du passé dans une vise nihiliste". ${ }^{42}$ Apesar de que talvez ele tenha derivado o termo "filologia ativa" de Deleuze, é evidente que a concepção de Barthes da prática como uma forma de nilismo é mais devedora de Derrida - bem como sua noção de "interprétation active" inspirada em Nietzsche - do que de Deleuze, para quem a ênfase em sua leitura de Nietzsche incide repetidamente na superação do niilismo através de um acolhimento do devir. Como Barthes também observa em 1971, o que ele compartilha mais profundamente com Derrida é "le sentiment de participer (de vouloir participer) à une phase historique que Nietzsche appelle le

uma palavra só quer dizer alguma coisa na medida que aquele que a diz quer alguma coisa ao dizê-la. E uma só regra: tratar a fala como uma atividade real, colocar-se do ponto de vista de quem fala. (...)A linguística ativa procura descobrir quem fala e quem nomeia." (grifo original).

${ }^{40}$ Sobre a concepção de Vattimo de "pensamento débil" ("pensiero debole"), cf., por ex., seu End of Modernity: Nihilism and Hermeneutics in Post-modern Culture, trans. por Jon R. Snyder (Cambridge: Polity Press, 1988). N.T.: edição brasileira: O fim da Modernidade: Niilismo e hermenêutica na cultura pós-moderna. Tradução de Eduardo Brandão. São Paulo: Martins Fontes, 2012.

${ }^{41}$ N.T.: "uma abertura absoluta do sentido"; "isenções de sentido, supresssões, anulações de sentido" (tradução nossa). Barthes, "Pour la libération d'une pensée pluraliste" (1973), em CEuvres complètes, ed. por Marty, II, 1699-1709 (p. 1703). Nessa entrevista, Barthes declara que Nietzsche tem 'beaucoup d'importance' (N.T.: "muita importância") para ele pois Nietzsche é um 'formulateur précisément et libérateur [...] d'une pensée pluraliste' (N.T.: "formulador com precisão e libertador (...) de um pensamento pluralista" (ibid.).

${ }^{42}$ Barthes, "Roland Barthes critique" (1971), em CEuvres complètes, ed. por Marty, II, 127880 (p. 1280). N.T. "ler o texto do passado com uma visão niilista". (tradução nossa). 
'nihilisme'". ${ }^{43} \mathrm{Um}$ ano depois, Barthes esclarece um ponto crucial no que concerne à sua concepção de niilismo, a saber, que embora para ele 0 niilismo seja "la seule philosophie possible de l'état dans lequel nous sommes", esse niilismo não deve ser confundido com nenhum tipo de "radicalité destructive". ${ }^{44}$ Ele não é uma forma de aniquilação, e não é revolucionário em espírito. É antes uma prática de tato, que trabalha nas margens de uma maneira discretamente subversiva. O tipo de nilismo nietzschiano que Barthes tem em mente é o que opera dentro da linguagem como uma forma de "réflexion" e "énonciation" (ibid.). (N.T.: "reflexão" e "enunciação"). Tal niilismo inspirado em Nietzsche é percebido como atos linguísticos que podem parecer ser "discrètes, étouffées, marginales, courtoises même" (N.T.: "discretos, sufocados, marginais, mesmo corteses"), mas que podem na verdade ser "plus nihilists, en profondeur, que des forms d'action apparemment plus radicales" (ibid.). (N.T.: "mais niilistas, em profundidade, que formas de ação aparentemente mais radicais"). Aqui, Barthes se distancia também dos soixante-huitards, e alinha-se com o tipo de abordagem desconstrutivista adotada por Derrida ao se tratar tanto de textos quanto de instituições. ${ }^{45}$

Como uma forma de niilismo desse modo concebida, a filologia ativa é uma "critique des sens", e, mais radicalmente ainda, uma "critique $d u$ sens". ${ }^{46}$ É um modo de ler-escrever que almeja desafiar qualquer apelo à verdade ou significado(s) de um texto. Portanto não é precisamente uma forma de "critique idéologique" do tipo que Barthes praticava antes em sua carreira, ${ }^{47}$ em obras como Mitologias e as intervenções coletadas em Essais critiques (1964), visto que, ao contrário da crítica ideológica, a filosofia ativa não assume a possibilidade de nenhum ponto estratégico inexorável, científico ou metalinguístico. Antes, trabalhando com o princípio de que não há leitura de um texto que possa ser estabelecida como correspondente aos "fatos", ou, de certo, a um sentido ou sentidos que sejam autoritários ou finais, a tarefa da

\footnotetext{
${ }^{43}$ Barthes, "Entretien", p. 1294. N.T. "o sentimento de participar (de querer participar) de uma fase histórica que Nietzsche chama o 'nilismo'" (tradução nossa).

${ }^{44}$ Barthes, "Fatalité de la culture, limites de la contre-culture" (1972), em CEuvres complètes, ed. por Marty, II, 1473-77 (p. 1476). N.T. "a única filosofia possível do estado em que estamos" (...) "radicalidade destrutiva". (tradução nossa).

${ }^{45}$ Contudo, há ocasiões em que Barthes de fato parece conceber o trabalho crítico como destrutivo. Em 1970, por exemplo, ele declara que o criticismo almeja "détruire" (N.T. "destruir"), mas sendo destruição aqui entendida "au sens large du terme, comme on parle, par exemple, de théologie negative" (N.T. "no sentido lato do termo, como se fala, por exemplo, em teologia negativa") (tradução nossa). (Barthes, '“'Express' va plus loin avec... Roland Barthes", p. 1020).

${ }^{46}$ Barthes, "Fatalité de la culture", p. 1477; grifo do autor do artigo. N.T. "crítica dos sentidos" (...) "crítica do sentido" (tradução nossa).

${ }_{47}$ Barthes, "Plaisir/écriture/lecture" (1972), em CEuvres complètes, ed. por Marty, II, 1478-89 (p. 1480). N.T. "crítica ideológica". (tradução nossa).
} 


\section{Criação \&}

filologia ativa se torna, como Barthes coloca em 1975, "libérer le texte - tous les textes - des théologies du signifié transcendental". ${ }^{48}$ Barthes deixa demasiadamente claro que essa concepção de filologia ativa é nietzschiana em sua inspiração ao declarar: "il faudrait chercher du côté de Nietzsche, là où il parle d"ébranler la vérité"” (ibid.). (N.T.: "seria necessário buscar em Nietzsche onde ele fala de 'abalar a verdade'"). No lugar da verdade do texto, a filologia ativa de Barthes visa o prazer do texto.

A distinção de Barthes, longe de consistente e certamente longe de estritamente binária, entre plaisir e jouissance (N.T.: "prazer" e "gozo") em $O$ Prazer do texto não só ecoa como reelabora a muito influente distinção de Nietzsche em O Nascimento da Tragédia entre o Apolíneo e o Dionisíaco, que por sua vez tem suas raízes nas distinções de Burke e depois Kant entre o belo e o sublime. De acordo com Nietzsche, o Apolíneo na arte é caracterizado por um prazer no belo, no transparente, no ordenado, e na imagem onírica (Traumbild), enquanto o Dionisíaco é caracterizado por um prazer altamente paradoxal na destruição, no desmantelamento do principium individuationis, e na embriaguez (Rausch). O prazer dionisíaco é, em suma, um "delicioso êxtase" (wonnevolle Verzückung). ${ }^{49}$ A reelaboração de Barthes dessa distinção faz do texto de plaisir o que "contente, emplit, donne de l'euphorie"; tal texto permanece dentro da cultura a partir do qual ele é produzido, e é experienciado através de "une pratique confortable de la lecture". ${ }^{50} \mathrm{O}$ texto de gozo, por outro lado, é o que "met en état de perte"; ele 'fait vaciller les assises historiques, culturelles, psychologiques, du lecteur', e, inevitavelmente, ele 'met en crise' a 'rapport au langage' do leitor (ibid.). Assim, a versão de Barthes do Dionisíaco é aquela em que o prazer deriva acima de tudo de uma crise de linguagem.

No entanto, para a filologia ativa de Barthes não se trata simplesmente de identificar textos que recaem em uma dessas duas categorias; isso é, textos cuja linguagem reforça o sentimento de poder linguístico do leitor, e textos que imergem o leitor em uma experiência de crise linguística. Fazê-lo significaria cair em um trabalho de classificação que dificilmente seria ativo em sentido nietzchiano. Ao invés disso, Barthes busca por meio de Nietzsche conceber e, acima de tudo, praticar uma filologia que tornaria os textos com

\footnotetext{
${ }^{48}$ Barthes, "Littérature/enseignement" (1975), em CEuvres complètes, ed. por Marty, III, 33743 (p. 342). N.T. "libertar o texto - todos os textos - das teologias do significado transcendental". (tradução nossa).

${ }^{49}$ Versão brasileira: Nietzsche, $O$ nascimento da tragédia. Tradução de Paulo César de Souza. São Paulo: Companhia de Bolso, 2020. p. 24.

${ }^{50}$ Barthes, Le Plaisir du texte (1973), em CEuvres complètes, ed. por Marty, II, 1493-1532 (p. 1501); grifo original. N.T.: "texto de prazer o que contenta, completa, dá euforia; que vem da cultura, não rompe com ela, está ligado a uma prática confortável da leitura". Texto de gozo: o que "põe em estado de perda", que "faz vacilar as bases históricas, culturais e psicológicas do leitor" (...) "coloca em crise sua relação com a linguagem". (tradução nossa).
} 


\section{Criação \&}

os quais ela se compromete textos de prazer, promovendo-se uma experiência de crise linguística, enquanto também se faz do próprio texto filológico um texto de prazer no sentido forte; a saber, um texto que leva o leitor a uma experiência de perda e desconforto, provocando-se uma crise na relação do leitor com a linguagem.

Apesar das próprias observações de Nietzsche sobre filologia serem relativamente poucas, na versão expandida de $A$ Gaia Ciência de 1886 ele explicitamente identifica a filologia como portadora de um impacto aniquilador sobre "toda a fé que repousa nos livros". ${ }^{51}$ A concepção de Barthes de filologia ativa certamente parece ecoar Nietzsche a esse respeito. No entanto, a concepção de Barthes de filologia ativa enquanto guiada pelo princípio nietzschiano de que todos os ditos fatos têm apenas existência linguística, e não se havendo assim senão interpretação, está em contradição direta com a própria definição de filologia de Nietzsche em $O$ Anticristo (1888), em que ele afirma que a filologia busca precisamente os "fatos" (Thatsachen), e que, por essa razão, a filologia é a própria antítese do "teólogo". Como diz Nietzsche:

Por filologia entenda-se aqui, em sentido bastante geral, a arte de ler bem - ser capaz de ler fatos sem falseá-los com interpretação, sem perder a cautela, paciência, a finura, no anseio de compreensão. ${ }^{52}$

Apesar desse compromisso com os "fatos" estar em desacordo com a concepcão de Barthes de filologia ativa não centrada na verdade, a próxima observação de Nietzsche em $O$ Anticristo está muito mais próxima da concepção de Barthes. Pois Nietzsche prossegue definindo a filologia como "ephexis [indecisão] na interpretação", 53 isto é, como uma suspensão hermenêutica do juízo, harmonizando essa definição com o que talvez seja a definição mais célebre de Nietzsche de filologia, no prefácio de Aurora (1881), como uma "arte" - ao invés de uma ciência - de "ler lentamente", uma "ourivesaria e saber da palavra, que tem trabalho sutil e cuidadoso a realizar, e nada consegue se não for lento". ${ }^{54} \mathrm{O}$ valor da filologia consiste, de acordo com Nietzsche, em nos ensinar "a ler bem, ou seja, lenta e profundamente, olhando para trás e para diante com segundas intenções,

\footnotetext{
${ }^{51}$ Versão brasileira: Nietzsche, A Gaia Ciência. Tradução de Paulo César de Souza. São Paulo: Companhia de Bolso, 2012. p. 232.

52 Versão brasileira: Nietzsche, O Anticristo. Tradução de Paulo César de Souza. São Paulo: Companhia de Bolso, 2016. p. 62. (grifo original).

53 Ibid.

54 Versão brasileira: Nietzsche, Aurora. Tradução de Paulo César de Souza. São Paulo: Companhia de Bolso, 2016. p. 14. (grifo original).
} 


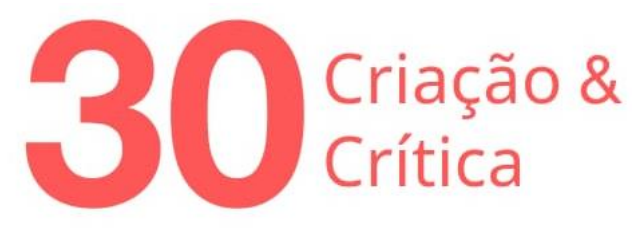

com portas abertas, com dedos e olhos delicados" (ibid.). Essa ênfase na incerteza, em certo ceticismo, e na delicadeza antecipa a própria prática de Barthes de uma filologia ativa.

O que dizer, contudo, dessa prática? Como, em suma, uma filologia ativa deve alcançar o cancelamento gerador de prazer do significado? Novamente, Nietzsche se mostra ser o guia de Barthes aqui. Pois a filologia ativa é, Barthes insiste, antes uma "cultura" do que um "método", no sentido de Nietzsche. Essa distinção nietzschiana entre dois modos de abordagem é elaborada bem ao começo do primeiro seminário de Barthes no Collège de France, Como viver junto. ${ }^{55}$ Como Derrida, para quem a desconstrução é uma perda tão logo quanto se torna um método, Barthes tenta evitar a abordagem aparentemente científica: um método seria fundamentado em princípios que possibilitassem um procedimento repetitivo, um que não leve suficientemente em conta as singularidades de um texto e do momento de sua leitura. Em contraste, para Barthes, todo texto é uma singularidade, e de fato uma constelação de singularidades, como o é todo ato de leitura, e é responsabilidade da filologia ativa responder de modos singulares aos textos. Assim, a filologia ativa não pode ser um programa; ela não pode saber ao certo aonde está indo. Ela envolve incerteza, desvio e surpresa. A cultura, enquanto distinta do método, como Barthes a entende, possibilita "une sorte de dispatching au tracé excentrique"; isso torna possível de se "tituber entre des bribes, des bornes de savoirs, de saveurs". ${ }^{56}$

Sublinhar esse argumento da filologia ativa ser antes uma cultura do que um método é uma concepção particular de experiência enquanto tal. Isso se torna claro quando Barthes cita uma passagem de Pierre Klossowski em Nietzsche e o círculo vicioso (1969) sobre a experiência como descontinuidade e, mais importante, sobre como a "fixité du langage" oculta essa descontinuidade existencial. Barthes descreve a passagem em questão como "très important", e tira disso a lição de que se rompendo essa fixidez linguística é possível acessar nosso "discontinu fondamental". ${ }^{57}$ Deve-se romper a fixidez da linguagem, de acordo com Barthes, por um processo de fragmentação. Essa fragmentação do discurso - a saber, tanto a fragmentação do texto quanto dos textos sendo lidos e dos próprios textos críticos - resulta no que Barthes denomina como uma "succession d'unités

\footnotetext{
${ }^{55}$ Cf. versão brasileira: Barthes, Como viver junto. Tradução de Leyla Perrone-Moisés. São Paulo: Martins Fontes, 2003. p. 5.

56 Versão brasileira: Barthes, Como viver junto. Tradução de Leyla Perrone-Moisés. São Paulo: Martins Fontes, 2003. p.7. N.T.: "uma espécie de dispatching de traçado excêntrico: titubear entre pedaços, marcos de saberes, de sabores."

${ }^{57}$ Versão brasileira: Barthes, Como viver junto. Tradução de Leyla Perrone-Moisés. São Paulo: Martins Fontes, 2003. p. 36-37. N.T.: "fixidez da linguagem"; "muito importante"; "discontínuo fundamental".
} 


\section{Criação \&}

discontinues", ou "traits" (ibid.) (N.T.: "sucessão de unidades descontínuas"; "traços"). O filólogo ativo, desse modo, deve buscar alcançar uma "pulverization de phrases, d'images, de pensées". 58

A pulverização linguística é evidente desde muito cedo no começo da vida escritural de Barthes. Ele procura praticar uma forma de escrita descontinuada em "Notes sur André Gide et son 'Journal" (1942) e então em Michelet (1954). Em suas notas sobre o Diário de Gide, Barthes não apenas produz uma série de fragmentos, enquanto cita Nietzsche, mas também justifica o fragmentário em termos que antecipam sua prática tardia de filologia ativa. A fragmentação nas notas do Diário de Gide serve, de acordo com Barthes, para que se evite fechar Gide dentro de um "système", julgando-se a descontinuidade e a incoerência das notas de Barthes como preferíveis a um comentário organizado que deformaria a obra (fragmentada) sobre a qual se comenta. ${ }^{59}$

Em sua biografia referência de Barthes, Tiphaine Samoyault adverte contra adotar de modo simplista a divisão do próprio Barthes de sua obra (em Roland Barthes por Roland Barthes) em fases distintas. ${ }^{60}$ Embora haja muitos motivos para que seja sustentada sua concepção de seu próprio desenvolvimento, inclusive a crescente importância do pensamento de Nietzsche para ele nos anos 1970, é também o caso de se levar em consideração certos aspectos chave já presentes no começo da obra de Barthes daquilo que ele veio a conceber como filologia ativa. A prática da fragmentação, que é de suma importância para a prática da filologia ativa de Barthes, talvez seja o exemplo mais marcante disso, dado que essa tem suas raízes bem no começo de sua escrita crítica. No entanto, é também o caso de uma pulverização ao nível da frase - e, de certo, ao nível da palavra - ser não apenas completamente exposta, como também completamente desenvolvida, nas obras escritas nos anos 1970, incluindo Roland Barthes por Roland Barthes e Fragmentos de um discurso amoroso, e, acima de tudo, nas notas de aula de Barthes para seus seminários no Collège de France entre 1976 e 1980. Barthes é o primeiro a reconhecer que, mesmo em seu ápice, tal fragmentação do texto produz um "faux discontinu", uma vez que se é impossível evitar fazer pelo menos algumas concessões para a fixidez da linguagem. ${ }^{61}$ Porém, ao se produzir um discurso fragmentário que pulverize 0 texto no qual se trabalha, o filólogo ativo está fazendo o que Barthes vê como

\footnotetext{
${ }^{58}$ Barthes, 'Vingt mots-clés pour Roland Barthes' (1975), em CEuvres complètes, ed. por Marty, III, 315-34 (p. 318). N.T.: "pulverização de frases, de imagens, de pensamentos". (tradução nossa).

${ }^{59}$ Barthes, "Notes sur André Gide et son 'Journal"' (1942), em CEuvres complètes, ed. por Marty, I, 23-33 (p. 23).

${ }^{60}$ Cf. Tiphaine Samoyault, Roland Barthes: biographie (Paris: Seuil, 2015), p. 585.

${ }^{61}$ Barthes, "Vingt mots-clés", p. 318.
} 


\section{Criação \&}

a "plus petite concession" (ibid.) (N.T.: "menor concessão") para a ideia da linguagem como fixada, confiável, e transmissora de sentido. A fragmentação do discurso é, assim, a abordagem menos ruim que há para o texto; ela é, para Barthes, um meio pelo qual se falha melhor como leitor.

Não menos importante que um comprometimento com a fragmentação discursiva, a filologia ativa não deve empregar conceitos, mas "conceptsmétaphores"; isso é, conceitos que permanecem inteiramente linguísticos, e cuja natureza linguística nunca é ocultada ou esquecida. Exemplos de tais conceitos-metáfora na obra de Barthes seriam a imagem-repertório, doxa, e a anti-histeria. A ideia de stadium e de punctum em A câmara clara cai na mesma categoria. Aqui também Nietzsche é exemplar para Barthes: "Si le mot est juste, si les concepts ont, comme il le dit, une origine métaphorique, alors c'est à cette origine que je me replace."62

É por conta dessa confiança nos conceitos-metáfora que a filologia ativa mantém sua distância crítica da filosofia, pelo menos enquanto discurso como concebido desde Platão. ${ }^{63}$ Embora não haja evidência que sugira que Barthes tivesse familiaridade com a obra de Fritz Mauthner, ${ }^{64}$ essa insistência sobre a origem metafórica de todos os conceitos está muito alinhada com a crítica do filósofo australiano que ele chama de "fetichismo da palavra" (Wortfetischismus), ou a confusão da linguística com alguma realidade extra-linguística; isso é, de "word for world" (N.T.: "palavra com mundo"). A diferença crucial é que, enquanto Mauthner advoga por uma "crítica da linguagem" (Kritik der Sprache) filosófica para que se liberte o pensamento desse fetichismo da palavra, Barthes defende o que ele vê como a base puramente linguística do conceitual, defendendo uma filologia em que a natureza metafórica do discurso seja destacada, mas não com o objetivo de superá-la. Para Barthes, em outras palavras, não há além-do-metafórico para o qual o filólogo ativo queira nos direcionar. Em vez disso, a tarefa da filologia ativa é relembrar incessantemente o leitor de que não há, nas palavras de Derrida, "hors-texte" (N.T.: "fora do texto") - nada além da metáfora. E, é

\footnotetext{
${ }^{62}$ Barthes, "A quoi sert un intellectuel?", p. 758. N.T.: "Se a palavra de Nietzsche é justa, se os conceitos têm, como ele disse, uma origem metafórica, então é a essa origem que eu remeto." (tradução nossa).

${ }^{63}$ A diferença fundamental entre filologia e filosofia é destacada por James Turner em Philology: The Forgotten Origins of the Modern Humanities (Princeton: Princeton University Press, 2014), pp. 381-86. A primeira é essencialmente mais hermenêutica e histórica; a segunda concebe a si mesma (pelo menos na tradição analítica) como "lógica, dedutiva, precisa em conclusões, desdenha da mudança ao longo do tempo" (p. 381). (tradução nossa).

${ }^{64} \mathrm{~A}$ ausência de qualquer tradução francesa das Contributions to a Critique of Language de Mauthner tornou isso um trabalho com o qual teria sido difícil de Barthes se envolver, e não há indícios de que ele o tenha feito.
} 


\section{Criação \&}

claro, se não há nada senão metáfora, então o próprio conceito de metáfora deve ser radicalmente revisto. ${ }^{65}$

No interior dessa textualidade sem fundo, a filologia ativa de Barthes deve trazer à luz o processo de "significação"; isso é, os modos com que um sentido de significado é produzido mesmo que nenhum significado nunca de fato se estabeleça. Para Barthes, essa "significação" toma a forma de um movimento de significante para significante, um processo de transformação sem fim, ou, nos termos de uma ideia nietzschiana que Barthes não cita, um eterno retorno ao texto em vez de um movimento do texto para o mundo. ${ }^{66}$ Se há uma diferença entre os textos de vanguarda e os outros, textos aparentemente mais realistas ou naturais, então essa reside apenas no fato de que os de vanguarda destacam sua própria "significação", enquanto os outros buscam escondê-la. A tarefa do filólogo ativo é desse modo tornada mais fácil pelo texto de vanguarda - é por isso que Barthes tratando de Sollers é, discutivelmente, muito menos interessante do que Barthes tratando de Balzac.

Assim como a filologia ativa busca lidar apenas com conceitosmetáfora, enquanto também se extingue a distinção entre o literal e o metafórico, do mesmo modo ela também almeja enfraquecer a distinção entre crítica e literatura. Isso é mais evidente não apenas em Roland Barthes por Roland Barthes, mas também na última obra publicada de Barthes, $A$ câmara clara, em que o "qui" prevalece sobre o "quoi". Apesar do fato de Barthes ter planejado escrever um romance nos últimos anos de sua vida possa parecer indicar que ele tinha uma clara distinção entre crítica e literatura, há também muito para que se sugira que sua concepção de filologia ativa era aquela em que o enfraquecimento dessa distinção tinha um papel crucial. A natureza do material coletado em inúmeras fichas de sumário que deveriam ser incluídas no romance em que ele estava trabalhando no momento de sua morte, bem como os planos para a obra, sob o título de "Vita Nova", tornam o dito enfraquecimento da distinção fiç̧ão-crítica evidente. ${ }^{67}$ Assim, a filologia ativa poderia servir como um termo guardachuva para ambas as linhas de escrita de Barthes.

O principal objetivo da filologia ativa de Barthes inspirada em Nietzsche é, no entanto, o que ele nomeia a "annulation du sens", uma forma

\footnotetext{
65 Derrida tenta fazer tal revista em "La Mythologie blanche", em Marges de la philosophie (Paris: Minuit, 1972), pp. 247-324.

${ }^{66} \mathrm{~A}$ falta de interesse de Barthes na ideia de eterno retorno está em notável contraste com a considerável atenção que lhe dá Deleuze e Klossowski.

${ }^{67}$ Como Samoyault observa, além dos vários planos que ele esboçou para essa obra (sob o título de "Vita Nova"), também há 1.064 fichas sumarizadas contendo material que ele desejara incluir na obra (cf. Samoyault, Roland Barthes, p.650). Sobre o planos de "Vita Nova", cf. CEuvres complètes, ed. por Marty, III, 1287-94 (fac-símiles) e 1299-1307 (transcrições).
} 


\section{Criação \&}

de negatividade ativa. ${ }^{68}$ É evidente que, para Barthes, alguns signos já são desprovidos de sentido. Em sua reflexão sobre a cultura japonesa, Barthes se alonga repetidamente na ideia de vazio, e em particular no "signe vide", tanto que o império dos signos japonês se torna certamente um império de signos vazios. ${ }^{69}$ Barthes se sente atraído pela cultura japonesa justamente porque não a compreende. Malgrado essa falta de conhecimento, ele argumenta que os signos na cultura japonesa são "vazios" porque eles não se referem a nenhum "signifié dernier", do tipo que no Ocidente se refere ao nome de Deus, ciência, razão ou lei. ${ }^{70}$ No entanto, é óbvio por si só que esse não é o caso de todos os signos, e então a questão se torna como o sentido poderia ser cancelado pelo filólogo ativo. Em O Império dos signos, já se faz aparente que o signo vazio possa ser o resultado de um processo ou de um procedimento. O modelo para escrever aqui é o Zen satori, que, Barthes argumenta, alcança uma "secousse du sens" tão radical que se abre para o "vide insubstituable" do sentido. ${ }^{71} \mathrm{O}$ objetivo é uma "exemption de tout sens" (ibid., p. 10). O gênero literário par excellence por tal negação de sentido é, de acordo com Barthes, o haicai, que "não quer dizer nada", apesar de ele permanecer "intelligible" e consequentemente nunca é inteiramente desprovido de sentido. ${ }^{72}$

O desafio se torna, então, como poderia tal esvaziamento de sentido ser alcançado pelo filólogo ativo sendo distinto do escritor de haicai. Em seu texto de 1973 sobre Bataille Le Gros Orteil, "As saídas do texto", no qual referências a Nietzsche abundam, ${ }^{73}$ Barthes explica que seu próprio texto

\footnotetext{
68 N.T.: "anulação do sentido". Barthes define "o Neutro" em termos nietzschianos de "negativo-ativo" (versão brasileira: Barthes, O Neutro; p. 166. Tradução de Ivone Castilho Benedetti, São Paulo: Martins Fontes, 2003).

${ }^{69} \mathrm{Cf}$. Barthes, O império dos signos (1970), versão brasileira na tradução de Leyla PerroneMoisés, São Paulo: Martins Fontes, 2007; p. 62. Exemplos dados por Barthes como de signos vazios incluem não apenas signos gráficos (como o "Mu"), mas também o centro da cidade de Tokyo, um pacote que contém o que se jogou fora, e o espelho. Barthes contrasta o espelho ocidental, que ele vê como um objeto narcíseo, em que o sujeito busca seu próprio reflexo, com o espelho oriental, que não apenas é "vazio", mas "símbolo do próprio vazio dos símbolos" (p. 102-103).

${ }^{70}$ Barthes, "“L'Express" va plus loin avec... Roland Barthes", p. 1024.

${ }^{71}$ Barthes, O império dos signos; p.10. N.T.: "sacudida do sentido"; "vazio insubstituível", tradução de Leyla Perrone-Moisés, São Paulo: Martins Fontes, 2007. Adiante, no mesmo livro, Barthes esclarece que o satori pode ser entendido como "une suspension panique du langage, le blanc qui efface en nous le règne des Codes", "uma suspensão pânica da linguagem, o branco que apaga em nós o reino dos Códigos", p. 98, na versão brasileira.

72 Ibid., p. 91. N.T.: "não quer dizer nada"; "inteligível", tradução de Leyla Perrone-Moisés, São Paulo: Martins Fontes, 2007. Desse modo não é de se surpreender que Barthes deva retornar ao haicai em seu seminário sobre a preparação do romance: para ele, o haicai permanece o gênero em que a "exemption du sens" é mais perfeitamente alcançada, sem que essa negação de sentido jamais resulte em algo completamente desprovido de sentido.

${ }^{73}$ Barthes não faz referência direta à obra do próprio Bataille sobre Nietzsche, Sur Nietzsche: volonté de chance (versão brasileira: Sobre Nietzsche: vontade de chance, editora
} 


\section{Criação \&}

consistirá em fragmentos nomeados, e que para que seja evitado qualquer sentido em que esses fragmentos sejam governados por uma "rhétorique du 'développement", eles serão organizados alfabeticamente, sendo essa ordem alfabética escolhida por ser "un ordre privé de sens". ${ }^{74}$ Uma abordagem similar é adotada para a organização dos fragmentos tanto de Roland Barthes por Roland Barthes e Fragmentos de um discurso amoroso. No entanto, mesmo quando a ordem não é alfabética, uma certa privação de sentido é alcançada, ou pelo menos o contrariamento de qualquer desenvolvimento retórico: é esse o caso das aulas do Collège de France. A arbitrariedade organizacional no arranjo dos fragmentos, que por sua vez fragmentam o(s) texto(s) que eles comentam, é, portanto, uma das principais estratégias de Barthes para cancelar uma certa forma de sentido, a saber, o sentido teleológico.

Dito isso, o cancelamento do sentido não deve ser adotado pelo filólogo ativo sem ambiguidade, pois a "moralidade" da filologia ativa reside precisamente no fato dela não ser apenas uma arte em detrimento da ciência, mas uma arte falida ou uma arte da falência. Fosse para ser alcançada a completa "annulation du sens", assim o filólogo ativo teria falhado da pior maneira possível, dado que qualquer cancelamento alcançado do sentido iria, de acordo com Barthes, resultar em "non-sens"; isso é dizer "le pire sens". ${ }^{75}$ Barthes desafia o haicai em seu último curso, $A$ preparação do romance, não apenas porque parece muito profundamente contra-intuitivo focar em um dos gêneros mais curtos de escrita literária ao abertamente focar no mais longo, mas porque, para Barthes, o haicai não produz nem "sens" nem "non-sens"(ibid.). Em outras palavras, o haicai aponta o caminho para o filólogo ativo: como se impedir que o sentido estabeleça a si mesmo, ao mesmo tempo se evitando o completo desaparecimento do sentido, que iria, paradoxalmente, implicar não apenas na restauração do sentido, mas no reinado do pior sentido possível. ${ }^{76} \mathrm{~A}$

autêntica), publicado pela primeira vez em uma edição limitada (Paris: Gallimard, 1945), e republicado no volume VI de suas CEuvres complètes (Paris: Gallimard, 1973), no ano seguinte da publicação do ensaio de Barthes Le Gros Orteil.

74 Barthes em "As saídas do texto", O rumor da língua. Tradução de Mario Laranjeira, São Paulo: WMF Martins Fontes, 2012. p. 300. N.T.: "retórica do 'desenvolvimento"; "uma ordem privada de sentido".

${ }^{75}$ Cf. Barthes, "Vingt mots-clés", p. 319.

${ }^{76}$ De acordo com Julia Kristeva, Barthes "donne sens au non-sens"; Pouvoirs et limites de la psychanalyse, I: Sens et non-sens de la revolte (Paris: Fayard, 1996), p. 445. Entretanto, seria mais preciso se dizer que Barthes reconhece que o "non-sens" tem um sentido, e de fato o pior sentido; ao invés de conferir sentido ao não sentido, ele busca um cancelamento do sentido que permaneça antes um processo do que uma conquista, e um que não seja realizável. 


\section{Criação \&}

política da filologia ativa reside precisamente nesse reconhecimento de que sempre há a ameaça de tal pior sentido possível na negação do sentido.

A concepção de filologia ativa de Barthes, bem como sua prática nos anos 1970, é então moldada de diversas maneiras pelo seu (altamente mediado) compromisso com o pensamento de Nietzsche, e acima de tudo com as obras do fim dos anos 1880. A dívida de Barthes com o que ele descreve como intertexto nietzschiano é profunda, moldando sua concepção de experiência, subjetividade, de estética e do papel do "artista" (como distinto do "sacerdote"), ${ }^{77}$ de necessidade de fragmentação, de natureza da interpretação, perspectivismo e pluralismo, conceitos e metáforas, da desvalorização niilista que caracteriza a modernidade, pathos, dramatização, da relação do corpo com a linguagem, e do enfraquecimento da distinção entre crítica e literatura.

Esses são, entretanto, importantes desvios de Nietzsche, bem como importantes variações de ênfase. Apesar dele de fato se referir ocasionalmente ao conceito de vontade de potência, o interesse de Barthes reside antes num modo de interpretação que busca atingir não a maestria, mas precisamente a incompetência, incerteza, e uma falência necessária. ${ }^{78}$ Em vez de ser a superação de uma forma de niilismo particular à modernidade, a filologia ativa de Barthes é ela mesma niilista; isso é melhor apontado pelo interesse de Barthes na ideia do "último niilista" do que pela figura do Übermensch. A filologia ativa é, resumidamente, uma forma de niilismo ativo, que se dirige em direção ao cancelamento do sentido ao invés da simples proliferação de sentidos. Se não raro se parece que tal proliferação de sentido é de fato o objetivo de Barthes, ele repetidamente gesticula em direção a algo mais radical e mais necessário: à aniquilação do sentido. E ainda assim, como vimos, essa aniquilação permanece num sentido muito específico impossível, precisamente porque, como o próprio Barthes observa, a ausência completa de sentido, ou não sentido, é ela própria um sentido, e de fato a pior forma de sentido. A "moralidade" da filologia ativa de Barthes inspirada em Nietzsche portanto reside em grande medida em seu comprometimento com o impossível. A experiência do filólogo ativo dessa impossibilidade - a impossibilidade da desaparição completa do sentido - é a experiência do "último niilista". Como observa Theodor Adorno na seção sobre o niilismo em Dialética Negativa (1966), a superação do

\footnotetext{
77 Como observa O’Meara, o "artista" nietzschiano (como oposto ao "sacerdote") é "o emblema ideal do novo semiologista de Barthes em Aula" (O'Meara, Roland Barthes, p. 71). ${ }^{78}$ Susan Sontag comenta a significante diferença de tom entre Nietzsche e Barthes, sendo o primeiro "principalmente agressivo" e o segundo "amável"; Sontag, "Writing Itself: On Roland Barthes', em A Barthes Reader, ed. por Sontag (London: Jonathan Cape, 1982), pp. viixxxviii (p. xvii). Essa diferença de tom reflete uma profunda diferença de atitude em face à questão da superação do niilismo.
} 


\section{Criação \&}

niilismo é ela própria a pior forma de niilismo. ${ }^{79} \mathrm{~A}$ esperança para o futuro não menos para o futuro da leitura - reside antes na experiência da falência da superação. A despeito disso, poucos falharam melhor que o filólogo ativo que Roland Barthes se tornou nos anos 1970, culminando-se nos seminários apresentados no Collège de France entre 1976 e 1980, nos quais a filologia ativa encontra uma de suas mais refinadas e perfeitamente acabadas formas.

\section{Referências:}

ADORNO, T. Dialética Negativa. Tradução de Marco Antonio Casanova. Rio de Janeiro: Zahar, 2009.

DELEUZE, G. Nietzsche e a filosofia. São Paulo: n-1 edições, 2018.

DERRIDA, A Escritura e a diferença. Paris: Seuil, 1967.

DERRIDA, J. A Escritura e a diferença. Tradução de Maria Beatriz Marques Nizza da Silva. São Paulo: Editora Perspectiva. $2^{a}$ edição.

BARTHES, R. Comment vivre ensemble: simulations romanesques de quelques espaces quotidiens. Notes de cours et de séminaires au Collège de France, 1976-1977, ed. por Claude Coste. Paris: Seuil/IMEC, 2002.

BARTHES, R. CEuvres complètes, 3 vols, ed. por Éric Marty. Paris: Seuil, 1995.

BARTHES, R. Le Lexique de l'auteur: séminaire à l'École pratique des hautes études 1973-1974. Suivi de fragments inédits du 'Roland Barthes par Roland Barthes', ed. por Anne Herschberg Pierrot. Paris: Seuil, 2010.

BARTHES, R. La Préparation du roman cours au Collège de France 19781979 et 1979-1980, ed. por Nathalie Léger. Paris: Seuil, 2015.

BARTHES, R. Como viver junto. Tradução de Leyla Perrone-Moisés. São Paulo: Martins Fontes, 2003.

BARTHES, R. Roland Barthes por Roland Barthes. Tradução de Leyla Perrone-Moisés. São Paulo: Estação Liberdade, 2003.

BARTHES, R. O império dos signos. Tradução de Leyla Perrone-Moisés, São Paulo: Martins Fontes, 2007.

BARTHES, R. O rumor da língua. São Paulo: WMF Martins Fontes, 2012.

BARTHES, R. O Neutro. Tradução de Ivone Castilho Benedetti. São Paulo: Martins Fontes, 2003.

KLOSSOWSLI, P. Nietzsche e o círculo vicioso. Paris: Mercure de France, 1969.

NIETZSCHE, F. Vie et vérité, ed. por Jean Garnier. Paris: Presses universitaires de France, 1971.

NIETZSCHE, F. A Gaia Ciência. Tradução de Paulo César de Souza. São Paulo: Companhia de Bolso, 2012.

NIETZSCHE, F. Aurora. Tradução de Paulo César de Souza. São Paulo: Companhia de Bolso, 2016.

\footnotetext{
${ }^{79}$ Versão brasileira: "Superações, mesmo aquelas ligadas ao niilismo, incluindo aí a superação nietzschiana que era pensada de uma maneira diversa e que, contudo, forneceu palavras de ordem ao fascismo, são sempre piores do que o que é superado." Theodor W. Adorno, Dialética Negativa, tradução de Marco Antonio Casanova. Rio de Janeiro: Zahar, 2009; p. 315.
} 


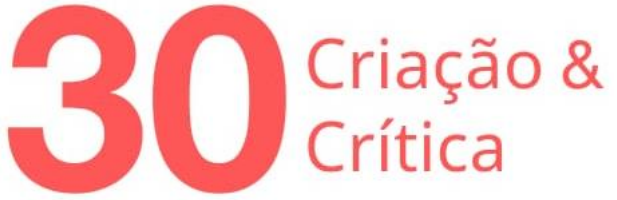

NIETZSCHE, F. O Anticristo. Tradução de Paulo César de Souza. São Paulo: Companhia de Bolso, 2016.

NIETZSCHE, F. O nascimento da tragédia. Tradução de Paulo César de Souza. São Paulo: Companhia de Bolso, 2020

NIETZSCHE, F. Obras incompletas / Friedrich Nietzsche. Tradução de Rubens Rodrigues Torres Filho. São Paulo: ed. 34, 2014.

NIETZSCHE, F. Writings from the Late Notebooks, ed. by Rüdiger Bittner, trans. by Kate Sturge. Cambridge: Cambridge University Press, 2003.

SAMOYAULT, T. Roland Barthes: biographie. Paris: Seuil, 2015.

SOLLERS, P. L'Amitié de Roland Barthes. Paris: Seuil, 2015.

VATTIMO. O fim da Modernidade: Niilismo e hermenêutica na cultura pósmoderna. Tradução de Eduardo Brandão. São Paulo: Martins Fontes, 2012.

Recebido em: 13/04/2021 Aceito em: 18/06/2021

Referência eletrônica: NOJIRI, Julia Bunemer. As palavras dançantes de Barthes. Criação \& Crítica, n. 30, p., set. 2021. Disponível em: $<$ http://revistas.usp.br/criacaoecritica>. Acesso em: dd mmm. aaaa. 